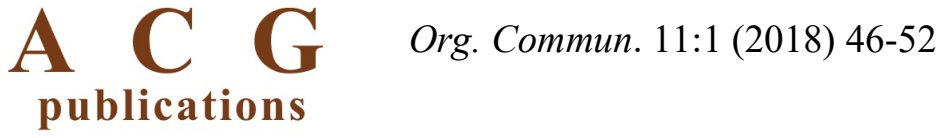

organic communications

\title{
Cycloaddition reactions of silacyclopropylidenoids to ethylene
}

\author{
Cem B. Yildiz ${ }^{\oplus, 1,2}$ and Akın Azizoglu ${ }^{\oplus, 2^{*}}$ \\ ${ }^{1}$ Department of Medicinal and Aromatic Plants, University of Aksaray, 68100 Aksaray, Türkiye \\ ${ }^{2}$ Laboratory of Computational Chemistry, Department of Chemistry, University of Balikesir, 10145 \\ Balıkesir, Türkiye
}

(Received July 31, 2017; Revised August 25, 2017; Accepted August 26, 2017)

\begin{abstract}
The cycloaddition reactions of silacyclopropylidenoids $\left(\mathrm{C}_{2} \mathrm{H}_{4} \mathrm{SiXLi}, \mathrm{X}=\mathrm{F}, \mathrm{Cl}, \mathrm{Br}\right)$ to ethylene have been investigated separately to gain insights into halogen and solvation effects on the energetic of the proposed reactions at the $\mathrm{B} 3 \mathrm{LYP} / 6-311+\mathrm{G}(\mathrm{d}, \mathrm{p})$ level of theory. The calculations reveal that the addition of silacyclopropylidenoids to ethylene occurs via stepwise mechanisms. The required initial energy barriers for the conversion of silacyclopropylidenoids to silaspiropentanes are determined to be $\Delta \mathrm{G}=77.4 \mathrm{~kJ} / \mathrm{mol}, 9.6 \mathrm{~kJ} / \mathrm{mol}$, and $9.2 \mathrm{~kJ} / \mathrm{mol}$ for $\mathrm{F}, \mathrm{Cl}$, and $\mathrm{Br}$, respectively. Furthermore, the gas phase calculations show that the reactions are not spontaneous at room temperature, whereas those of THF solvated models indicate that the formations of silaspiropentanes are spontaneous in the cases of $\mathrm{X}=\mathrm{Br}$ and $\mathrm{Cl}$. Additionally, the findings show that the silacyclopropylidene addition to ethylene is determined to be exergonic in both gas and THF phases by $\Delta \mathrm{G}=-$ $42.6 \mathrm{~kJ} / \mathrm{mol}$ and $-39.3 \mathrm{~kJ} / \mathrm{mol}$, respectively.
\end{abstract}

Keywords: Silacyclopropylidenoids; silylenoid; silaspiropentane; reaction mechanism; DFT. C2018 ACG Publications. All rights reserved.

\section{Introduction}

Carbenoids are compounds which have an electropositive metal and halogen are bound to the same carbon atom and have been known as highly reactive carbon species in organic chemistry. ${ }^{1-3}$ The silicon analogue of simple carbenionds, $\mathrm{H}_{2} \mathrm{SiLiX}, \mathrm{X}=\mathrm{F}, \mathrm{Cl}$, or $\mathrm{Br},{ }^{4,5}$ are most often key intermediates in many organometallic and organosilicon reactions and having considerable attention due to their applications to experimental and theoretical fields. ${ }^{6-11}$ In 1995, Tamao and Kawachi explored the existence of a silylenoid and examined its chemical properties. ${ }^{11}$ However, only limited stable silylenoids have been characterized up to now because of their highly reactive nature. A number of halosilylenoid compounds from the reaction of $\mathrm{TsiSiX}_{3}\left[\mathrm{Tsi}=\mathrm{C}\left(\mathrm{SiMe}_{3}\right)_{3}, \mathrm{X}=\mathrm{Br}, \mathrm{Cl}\right]$ with lithium naphthalenide were published by Lee et al. ${ }^{13}$ Apeloig et al. disclosed formation of fluorosilylenoid from the reaction of bromofluorosilane with silyl lithium in $2006 .{ }^{12}$ Despite considerable potential in this regard, ${ }^{9,14,15}$ reports on those of cyclic analogues $\left(\mathrm{C}_{2} \mathrm{H}_{4} \mathrm{SiLiX}, \mathrm{X}=\mathrm{F}, \mathrm{Cl}\right.$, or $\left.\mathrm{Br}\right)$ are still rare. ${ }^{16-18}$ Very recently, we have performed a series of theoretical calculations on the formation and rearrangement of silaspiropentane 2 from addition of lithium-bromosilacyclopropylidenoid $\mathbf{1 B r}$ to ethylene (Scheme 1). ${ }^{18}$ The nature of the addition reaction of $\mathbf{1}$ to ethylene is found to be endergonic by $\Delta \mathrm{G}=33.9 \mathrm{~kJ} / \mathrm{mol}$, whereas the formation process of 4 is exergonic by $\Delta \mathrm{G}=-60.6 \mathrm{~kJ} / \mathrm{mol}$ at the $\mathrm{B} 3 \mathrm{LYP} / 6-31+\mathrm{G}(\mathrm{d}, \mathrm{p})$ level of theory.

* Corresponding author: E-Mail: azizoglu@balikesir.edu.tr , Tel: + 902666121000 -; fax: + 902666121410 


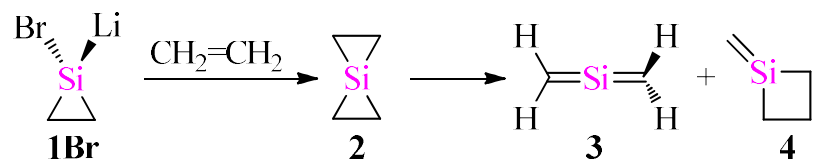

Scheme 1. General representation of the proposed intermolecular addition of $1 \mathrm{Br}$ to 2 and intramolecular rearrangement of $\mathbf{2}$ to 3 and 4 .

In the present computational study, we would like to distil a general message for the effects of halogen and solvent (Tetrahydrofuran, THF) on the possible cycloaddition reactions of silacyclopropoylidenoids $\left(\mathrm{C}_{2} \mathrm{H}_{4} \mathrm{SiLiX}\right.$, denoted as $\mathbf{1 X}$ with $\mathrm{X}=\mathrm{C}, \mathrm{Si}$, or $\left.\mathrm{Ge}\right)$ to $\mathrm{C}=\mathrm{C}$ double bond of ethylene. As we will show, the reactions proceed in stepwise manner in all case. The nature of the reactions is shown to depend heavily on the phase (Gas or THF) and halogen ( $\mathrm{X}=\mathrm{F}, \mathrm{Cl}$, or $\mathrm{Br}$ ) of the calculations.

\section{Experimental}

All the computations were carried out by Gaussian $09 \mathrm{~W}$ packed program. ${ }^{19}$, Density functional theory (B3LYP with $6-311+\mathrm{G}(\mathrm{d}, \mathrm{p})$ basis set) was employed to locate the studied compounds on their potential energy surface. The optimized structures were determined by characterization of their Hessian matrix as a minimum (no imaginary frequency) or transition state. The intrinsic reaction coordinate (IRC) procedure was carried out for the identification of the connectivity of stationary points on the respective potential energy surfaces with the algorithm of Gonzalez-Schlegel. ${ }^{20,21}$ The frequency calculations of THF (Tetrahydrofuran) solvated models have been done for the optimized structures with using polarized continuum model (PCM) solvation model to estimate solvent effect on the energetic of the reactions. ${ }^{22}$ The optimized structures were visualized by using the GaussView 3.0 program. ${ }^{23}$

\section{Results and Discussion}

Hence, we have started optimization of most stable $\mathbf{S}$ form of $\mathrm{C}_{2} \mathrm{H}_{4} \mathrm{SiLiX}$ from silacyclopropylidenoid (S), tetrahedral (T), and inverted (I) forms (Scheme 2). ${ }^{24}$

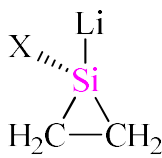

(S)<smiles>[Y][Si]1([AlH])CC1</smiles>

(T)<smiles>[Y][SiH]1CC1</smiles>

(I)

Scheme 2. The silacyclopropylidenoid (S), tetrahedral (T), and inverted (I) forms of $\mathrm{C}_{2} \mathrm{H}_{4} \mathrm{SiLiX}$ (where $\mathrm{X}=\mathrm{F}, \mathrm{Cl}, \mathrm{Br}$ ).

Then, the $\mathbf{S}$ forms with $\mathrm{F}, \mathrm{Cl}$, and $\mathrm{Br}$ are selected as reactant for the proposed reactions and those of van der Waals complexes $(\mathbf{5 F}, \mathbf{5 C l}$, and $\mathbf{5 B r})$ are optimized on their potential energy surfaces (PES) at the B3LYP/6-311+G(d,p) level of theory (Figure 1-3). The C1-Li and C2-Li bond distances of 5F are determined to be $2.440 \AA$ and $2.453 \AA$, respectively (Figure 1). As the addition reaction continues, TS1F is formed by $\Delta \mathrm{G}^{\neq}=94.6 \mathrm{~kJ} / \mathrm{mol}$. The theoretical computations indicate that the $\mathrm{C} 2$ atom of the ethylene unit becomes connected $(2.073 \AA)$ to counter ion $\mathrm{Li}^{+}$and the $\mathrm{Si}$ atom of the silacyclopropylidenoid moiety moves to the $\mathrm{C} 1$ atom to form a related TS1F structure along the potential energy surface. As it can be seen from Figure 1, the $\mathrm{C} 2-\mathrm{Li}$ bond distance in TS1F is considerably shortened as compared to that of $\mathbf{5 F}(2.433 \AA$ ), whereas $\mathrm{C} 1-\mathrm{C} 2$ bond length in $\mathbf{5 F}$ is elongated with $0.083 \AA$. The geometry changes along with TS1F promotes formation of $6 \mathbf{F}$. The calculated energy barrier from $\mathbf{6 F}$ to TS1F was obtained to be $\Delta \mathrm{G}^{\neq}=46.9 \mathrm{~kJ} / \mathrm{mol}$. A newly formed $\sigma-$ 
bond between $\mathrm{Si}-\mathrm{C} 1$ is existed with a bond length of $1.859 \AA$ in $\mathbf{6 F}$. Subsequently, the liberation of LiF from the resulting intermediate $\mathbf{6 F}$ to generate silacyclopropene- $\mathrm{LiF}$ complex $\mathbf{7 - L i F}$ via $\mathbf{T S 2 F}$ needs energy barrier of $\Delta \mathrm{G}^{\neq}=+46.4 \mathrm{~kJ} / \mathrm{mol}$. Compared with $\mathbf{6 F}$, the $\mathrm{Si}-\mathrm{C} 2$ and $\mathrm{Li}-\mathrm{F}$ bond lengths in TS2F are decreased by $0.807 \AA$ and $\AA 0.171 \AA$, respectively. Then, the three-membered ring moiety of 7- $\mathbf{L i F}$ is formed by the backward energy of $\Delta \mathrm{G}=4.6 \mathrm{~kJ} / \mathrm{mol}$, so that the overall pathway for 7- $\mathbf{L i F}$ is decidedly endergonic by $\Delta \mathrm{G}=72.3 \mathrm{~kJ} / \mathrm{mol}$ (Figure 1). Collectively, the mechanistic pathway of $\mathbf{1 F}$ is appeared to bear a reasonable resemblance to our previous report on $\mathbf{1 B r}$ reaction. ${ }^{18}$

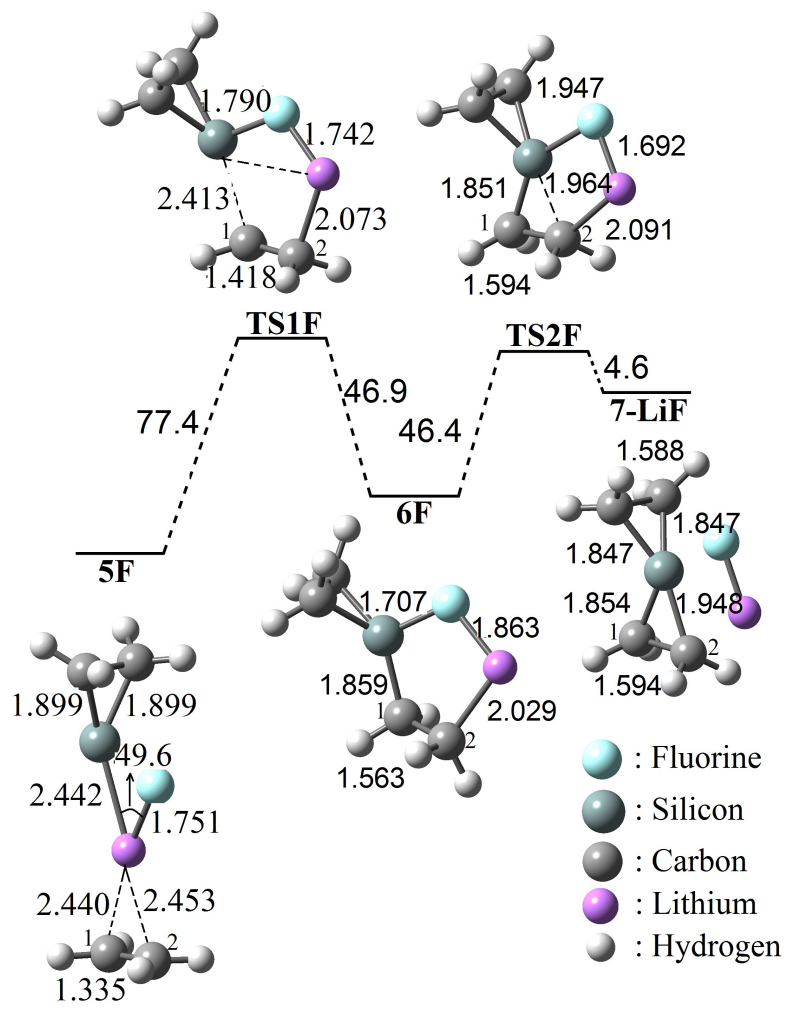

Figure 1. The proposed addition reaction mechanism of $1 \mathrm{~F}$ to ethylene.

The exchange of the halogen atom with chlorine and bromine $(\mathrm{X}=\mathrm{Cl}$ or $\mathrm{Br})$ has a minor mechanistic impact: instead of two steps mechanisms now three steps processes via $\mathbf{8 X}(\mathrm{X}=\mathrm{Cl}$ or $\mathrm{Br})$ lead to silaspiropentane compound. The initial required energy barriers to $\mathbf{8 X}(\mathrm{X}=\mathrm{Cl}$ or $\mathrm{Br})$ are determined to be very similar by $\Delta \mathrm{G}^{\neq}=+9.6 \mathrm{~kJ} / \mathrm{mol}$ and $9.2 \mathrm{~kJ} / \mathrm{mol}$, respectively (Figure 2 and 3). The structure $\mathbf{8 X}$ can be described as distorted form of $\mathbf{5 X}$ with the obtained structural properties. For instance, the $\mathrm{C} 1-$ $\mathrm{Li}(2.456 \AA), \mathrm{C} 2-\mathrm{Li}(2.449 \AA)$, and $\mathrm{C} 1-\mathrm{C} 2(1.334 \AA)$ bond lengths in $\mathbf{8 C l}$ are determined to be very similar as compared to those of in $\mathbf{5 C l}(2.430 \AA, 2.439 \AA$, and $1.335 \AA)$, respectively (Figure 2). The required energy barriers for the coordination of $\mathrm{Si}$ and $\mathrm{Li}^{+}$atoms to the $\mathrm{C} 1$ and $\mathrm{C} 2$ atoms to form related intermediates $\mathbf{6 X}$ via TS1X were calculated to be $\Delta \mathrm{G}^{\neq}=116.3$ and $119.3 \mathrm{~kJ} / \mathrm{mol}$ for $\mathrm{X}=\mathrm{Cl}$

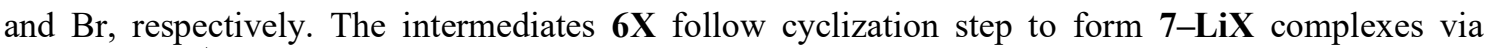
TS2X by $\Delta \mathrm{G}^{\neq}=30.9 \mathrm{~kJ} / \mathrm{mol}$ for $\mathrm{Cl}$ and $30.1 \mathrm{~kJ} / \mathrm{mol}$ for $\mathrm{Br}$. The results indicate that formations of 7LiCl and 7- $\mathbf{L i B r}$ are endergonic by $23.8 \mathrm{~kJ} / \mathrm{mol}$ and $27.3 \mathrm{~kJ} / \mathrm{mol}$, respectively. Thus, the gas phase calculations at room temperature suggest that the reactions are plausible but not spontaneous at room temperature. 


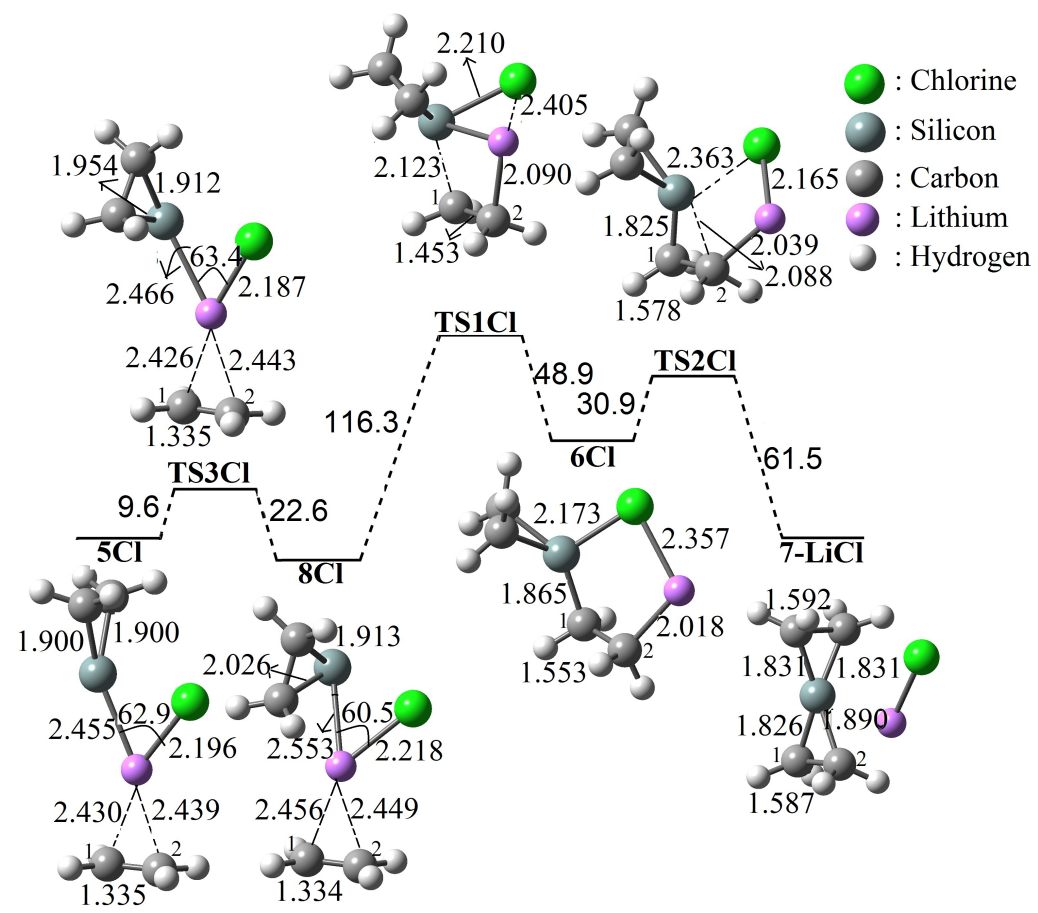

Figure 2. The proposed addition reaction mechanism of $\mathbf{1 C l}$ to ethylene.

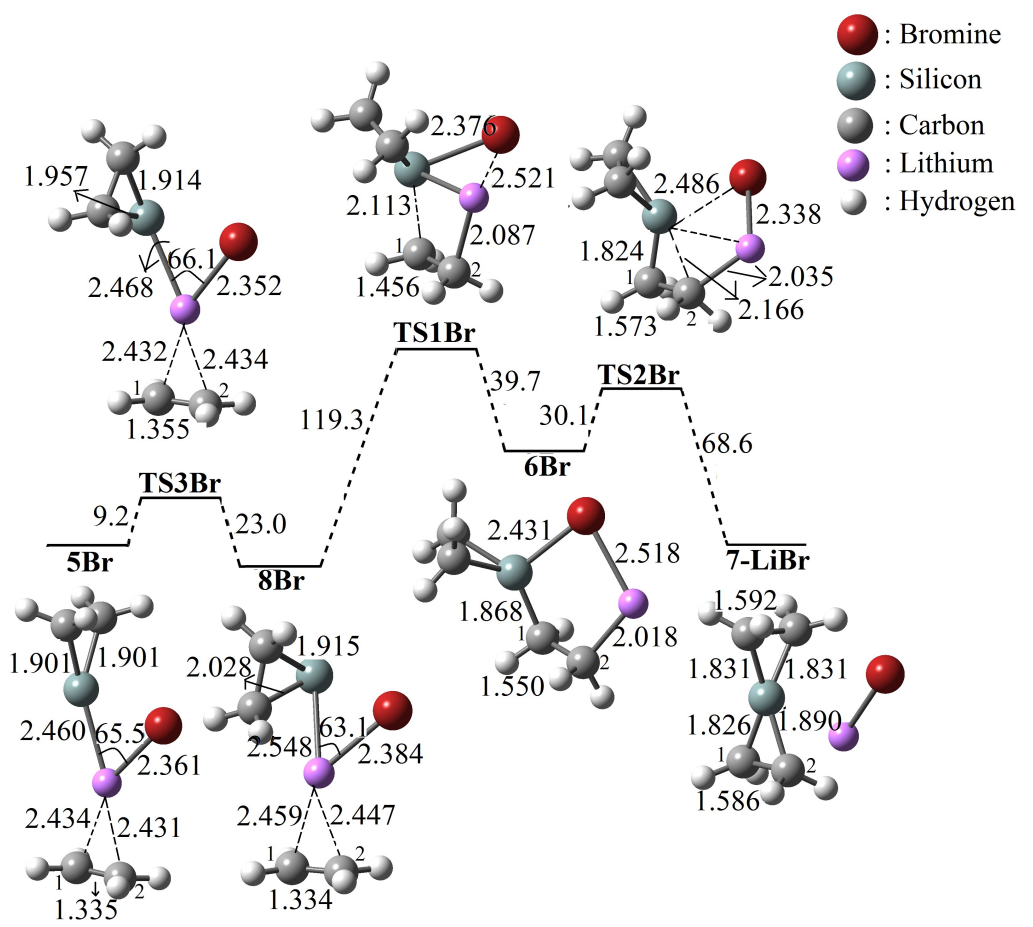

Figure 3. The proposed addition reaction mechanism of $1 \mathrm{Br}$ to ethylene.

We also calculated the possible mechanism of the cycloaddition reaction between silacyclopropylidene 9 and ethylene to evaluate effect of LiX. DFT calculations on the mechanism predict free energy barrier of $\Delta \mathrm{G}^{\neq}=32.6 \mathrm{~kJ} / \mathrm{mol}$ for TS4 after formation of van der Waals complexes 10, so that the overall pathway for $\mathbf{1 1}$ is decidedly exergonic by $\Delta \mathrm{G}=-42.6 \mathrm{~kJ} / \mathrm{mol}$ in gas phase (Figure 4). It can be seen that the nature of the reactions $\mathbf{1 F}, \mathbf{1 C l}$, and $\mathbf{1 B r}$ with ethylene are all endergonic, showing that the reactions are nonspontaneous and not favorable in gas phase, whereas the 
addition of silacyclopropylidene 9 to ethylene is promising with exergonic character of the proposed reaction.

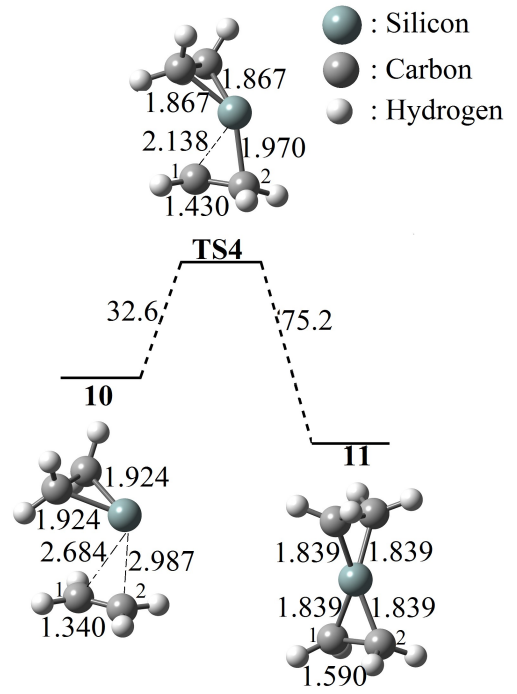

Figure 4. The proposed addition reaction mechanism of 9 to ethylene.

To obtain more insights on the energetics of the mechanisms, the implicit solvation models with PCM method was performed. It is well known from the literature that carbenes, carbenoids, and those of heavier analogues can be stabilized by using donor solvents, such as THF, diethyl ether, toluene, etc. $^{12,13}$ Based on these observations, tetrahydrofuran (THF) was chosen as solvent for the addition reactions to form 7-LiX. The frequency calculations of the optimized structures estimate that the required activation energies are decreased for TS1X and TS2X, whereas those of TS3X forms are increased as compared to gas phase calculations (Table 1). Moreover, the final products 7-LiCl and 7$\mathrm{LiBr}$ are determined to be considerably exergonic by the overall energies of $\Delta \mathrm{G}=-17.3 \mathrm{~kJ} / \mathrm{mol}$ and $12.6 \mathrm{~kJ} / \mathrm{mol}$ in the cases of $\mathrm{X}=\mathrm{Cl}$ and $\mathrm{Br}$. However, the structure of 7-LiF has endergonic nature on its potential energy surface by $\Delta \mathrm{G}=-18.2 \mathrm{~kJ} / \mathrm{mol}$.

Table 1. The solvent effect on the energetic of the reactions at B3LYP/6-311+G(d,p) level of theory (energies in $\mathrm{kJ} / \mathrm{mol}$, Solvent $=\mathrm{THF}$ ).

\begin{tabular}{cccccc}
\hline & TS3 & TS1 & TS2 & TS4 & The overall $\mathbf{\Delta G}$ \\
\hline $\mathbf{5 F}$ & - & 50.6 & 21.8 & - & +18.2 \\
$\mathbf{5 C l}$ & 14.6 & 96.5 & 27.5 & - & -17.3 \\
$\mathbf{5 B r}$ & 12.9 & 100.0 & 23.0 & - & -12.6 \\
$\mathbf{1 0}$ & - & - & - & 33.8 & -39.3 \\
\hline
\end{tabular}

\section{Conclusion}

The energetic of the addition reactions of silacyclopropylidenoids $(\mathbf{1 X}, \mathrm{X}=\mathrm{F}, \mathrm{Cl}$, or $\mathrm{Br})$ are compared and the contribution of the halogens to the reactivity of the structures is simply discussed. The calculations depict that the reactions follow stepwise fashion for silacyclopropylidenoid (1X, $\mathrm{X}=$ $\mathrm{F}, \mathrm{Cl}$, or $\mathrm{Br}$ ) additions, whereas silacyclopropylidene $\mathbf{1 0}$ addition occurs in a concerted manner. The

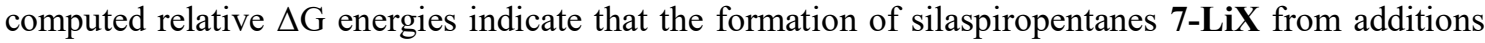
of $1 \mathrm{X}$ to ethylene are endergonic by $\Delta \mathrm{G}=72.3 \mathrm{~kJ} / \mathrm{mol}, 23.8 \mathrm{~kJ} / \mathrm{mol}$, and $27.3 \mathrm{~kJ} / \mathrm{mol}$ for $\mathrm{F}, \mathrm{Cl}$, and $\mathrm{Br}$ in gas phase, respectively. Conversely, the THF solvated systems for $\mathbf{1 C l}$ and $\mathbf{1 B r}$ are determined to be exergonic by $\Delta \mathrm{G}=-17.3 \mathrm{~kJ} / \mathrm{mol}$ and $-12.6 \mathrm{~kJ} / \mathrm{mol}$, respectively. In the case of silacycloproylidene 9 addition, the reaction is also exergonic in both gas and THF phases by $\Delta \mathrm{G}=-42.6 \mathrm{~kJ} / \mathrm{mol}$ and -39.3 
$\mathrm{kJ} / \mathrm{mol}$, respectively. On the basis of theoretical results, the THF solvated pathways with $\mathrm{X}=\mathrm{Cl}$ and $\mathrm{Br}$ are more promising with exergonic characters of the proposed reactions.

\section{Acknowledgements}

This work was partially supported by Aksaray University (BAP-2016-024) and TUBITAK (Grant No: KBAG-212T049).

\section{Supporting Information}

Supporting information accompanies this paper on http://www.acgpubs.org/OC

\section{ORCID}

Cem Burak Yıldiz: 0000-0002-0424-4673

Akin Azizoglu: 0000-0002-5098-1842

\section{References}

[1] Mieusset, J. L.; Brinker, U. H. On the existence of uncharged molecules with a pyramidally coordinated carbon: the cases of pentacyclo $\left[4.3 \cdot 0.0^{2,9} \cdot 0^{3,8} \cdot 0^{7,9}\right]$ non-4-ene and heptacyclo$\left[7.6 .0 .0^{1,5} \cdot 0^{5,15} \cdot 0^{6,14} \cdot 0^{10,14} \cdot 0^{10,15}\right.$ pentadecane. J. Org. Chem. 2005, 70, 10572-10575.

[2] Averina, E. B.; Sedenkova, K. N.; Borisov, I. S.; Grishin, Y. K.; Kuznetzova, T. S.; Zefirov, N. S. Unusual methylation reaction of gem-bromofluorospiropentanes with methyllithium. Tetrahedron 2009, 65, 5693-5701.

[3] Kilbas, B.; Azizoglu, A.; Balci, M. Endo- and exo-configured cyclopropylidenes incorporated into the norbornadiene skeleton: generation, rearrangement to allenes, and the effect of remote substituents on carbene stability. J. Org. Chem. 2009, 74, 7075-7083.

[4] Escudie, J.; Ranaivonjatovo, H.; Bouslikhane, M.; Harouch, Y. E.; Baiget, L.; Nemes, G. C. Phosphasila-, phosphagerma-, and phosphaarsaallenes $\mathrm{P}=\mathrm{C}=\mathrm{E}(\mathrm{E}=\mathrm{Si}, \mathrm{Ge}, \mathrm{As})$ and arsa- and diarsaallenes $\mathrm{As}=\mathrm{C}=\mathrm{E} "(\mathrm{E} "=\mathrm{C}$, As). Russ. Chem. Bull. Int. Ed. 2004, 53, 1020-1033.

[5] Escudie, J.; Ranaivonjatovo, H. Group 14 and 15 heteroallenes $\mathrm{E}=\mathrm{C}=\mathrm{C}$ and $\mathrm{E}=\mathrm{C}=\mathrm{E}^{`}$. Organomet. 2007, 26, 1542-1559.

[6] Gaspar, P.; West, R. The Chemistry of Organic Silicon Compounds, Wiley, New York, 1998.

[7] Lee, V. Y.; Sekiguchi, A. Novel organometallic reagents: geminal dianionic derivatives of the heavy group 14 elements. Inorg. Chem. 2011, 50, 12303-12314.

[8] Clark, T.; Schleyer, P. v. R. The isomeric structures of $\mathrm{SiH}_{2}$ LiF. J. Organomet. Chem. 1980, 191, $347-$ 353.

[9] Feng, D. C.; Feng, S. Y.; Deng, C. H. Theoretical study on the addition reaction of silylenoid H2SiLiF and ethylene. Chem. J. Chin. Univ. 1996, 17, 1108-1111.

[10] Zhang, M.; Li, W.; Li, O.; Cheng, J. A new exploration of the addition reaction of the silylenoid $\mathrm{H}_{2} \mathrm{SiLiF}$ with ethylene. J. Mol. Model. 2015, 21, 202-207.

[11] Tamao, K.; Kawachi, A. The chemistry of silylenoids: preparation and reactivity of (alkoxysilyl)lithium compounds. Angew. Chem. Int. Edit. 1995, 34, 818-820.

[12] Molev, G.; Bravo-Zhivotovakii, D.; Karni, M.; Tumanskii, B.; Botoshansky, M.; Apeloig, Y. Synthesis, molecular structure, and reactivity of the isolable silylenoid with a tricoordinate silicon. J. Am. Chem. Soc. 2006, 128, 2784-2785.

[13] Lee, M.; Hyeon, M.; Lim, Y.; Choi, J.; Park, C.; Jeong, S.; Lee, U. Syntheses and reactivities of stable halosilylenoids, $(\mathrm{Tsi}) \mathrm{X}_{2} \mathrm{SiLi}\left(\mathrm{Tsi}=\mathrm{C}\left(\mathrm{SiMe}_{3}\right)_{3}, \mathrm{X}=\mathrm{Br}, \mathrm{Cl}\right)$. Chem. Eur. J. 2004, 10, 377-381.

[14] Qi, Y. H.; Ma, J.; Xu, C. J.; Geng, B.; He, M. X. Computational investigations on the electronic and structural properties of the unsaturated silylenoid HP = SiLiF. J. Mol. Model. 2014, 20, 2213-2218.

[15] Flock, M.; Marschner, C. Silyl anions or silylenoids? - A DFT study of silyllithium compounds with $\pi$ donating substituentsChem. Eur. J. 2005, 11, 4635-4642.

[16] Azizoglu, A.; Yildiz, C. B. Ring-opening mechanismof lithium bromosilacyclopropylidenoids to silaallenes. Organomet. 2010, 29, 6739-6743.

[17] Azizoglu, A.; Yildiz, C. B. Ring-opening mechanism of disilacyclopropylidenoids and trisilacyclopropylidenoid: a theoretical study. J. Organomet. Chem. 2012, 715, 19-25. 
[18] Yildiz, C. B.; Azizoglu, A. A mechanistic investigation on the formation and rearrangement of silaspiropentane: a theoretical study. J. Mol. Model. 2016, 22, 158-164.

[19] Frisch, M. J.; Trucks, G. W.; Schlegel, H. B.; Scuseria, G. E.; Robb, M. A.; Cheeseman, J. R.; Montgomery, Jr., J. A.; Vreven, T.; Kudin, K. N.; Burant, J. C.; Millam, J. M.; Iyengar, S. S.; Tomasi, J.; Barone, V.; Mennucci, B.; Cossi, M.; Scalmani, G.; Rega, N.; Petersson, G. A.; Nakatsuji, H.; Hada, M.; Ehara, M.; Toyota, K.; Fukuda, R.; Hasegawa, J.; Ishida, M.; Nakajima, T.; Honda, Y.; Kitao, O.; Nakai, H.; Klene, M.; Li, X.; Knox, J. E.; Hratchian, H. P.; Cross, J. B.; Bakken, V.; Adamo, C.; Jaramillo, J.; Gomperts, R.; Stratmann, R. E.; Yazyev, O.; Austin, A. J.; Cammi, R.; Pomelli, C.; Ochterski, J. W.; Ayala, P. Y.; Morokuma, K.; Voth, G. A.; Salvador, P.; Dannenberg, J. J.; Zakrzewski, V. G.; Dapprich, S.; Daniels, A. D.; Strain, M. C.; Farkas, O.; Malick, D. K.; Rabuck, A. D.; Raghavachari, K.; Foresman, J. B.; Ortiz, J. V.; Cui, Q.; Baboul, A. G.; Clifford, S.; Cioslowski, J.; Stefanov, B. B.; Liu, G.; Liashenko, A.; Piskorz, P.; Komaromi, I.; Martin, R. L.; Fox, D. J.; Keith, T.; Al-Laham, M. A.; Peng, C. Y.; Nanayakkara, A.; Challacombe, M.; Gill, P. M. W.; Johnson, B.; Chen, W.; Wong, M. W.; Gonzalez, C.; and Pople, J. A. Gaussian 09, revision A02. Gaussian Inc, Wallingford (2009).

[20] Fukui, K. The path of chemical reactions the IRC approach. Acc. Chem. Res., 1981, 14, 363-368.

[21] Gonzalez, C.; Schlegel, H. B. Improved algorithms for reaction path following: higher-order implicit algorithms. J. Chem. Phys. 1991, 95, 5853-5860.

[22] Miertuš, S.; Scrocco, E.; Tomasi, J. Electrostatic interaction of a solute with a continuum. A direct utilizaion of AB initio molecular potentials for the prevision of solvent effects. J. Chem. Phys. 1981, 55, 117-129.

[23] Dennington, R. II.; Keith, T.; Millam, J.; Eppinnett, K.; Hovell, W. L.; Gilliland, R. GaussView v.5.0.9 Visualizer and Builder. Gaussian 09. Wallingford, CT (2009).

[24] Yildiz, C. B. Azizoglu, A. Theoretical study on the structures and stabilities of silacyclopropylidenoids. Struct. Chem. 2012, 23, 1777-1784.

\section{A C G \\ publications \\ (C) 2018 ACG Publications}

